\title{
JERZY TOPOLSKI - IN MEMORIAM
}

\section{Anno TOPOLSKA}

I am honored to be here and speak to you today in memory of my dear father. In two days we will celebrate his 88 th birthday. I am glad that we can gather on this occasion, not just to commemorate my father, but to remember him and learn from his legacy. As we have heard, he was a special person for so many people: his followers, his friends, his students and, of course, us - his family. He was a very warm person, with a lot of energy, many ideas, and who always worked hard. His bibliography includes over 1100 works, including 30 books, numerous articles and reviews, and much more. Even as he devoted his professional life to developing the Pol-

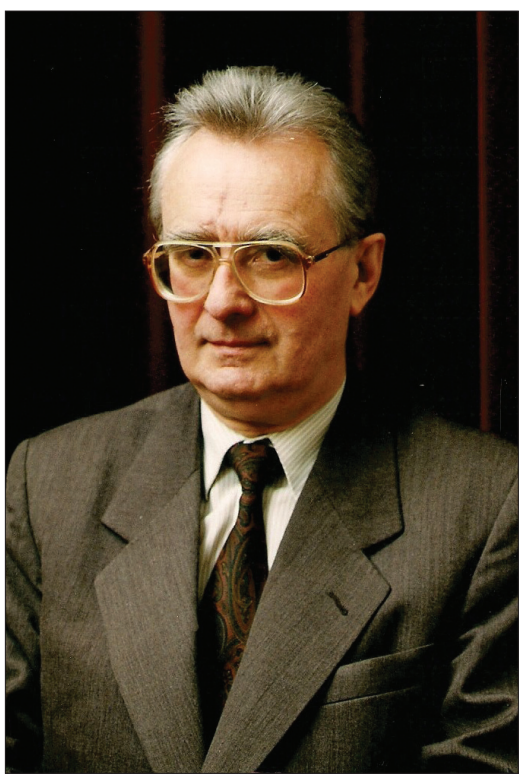
ish humanities, however, he was always present for his family.

This is a photo of my father as I remember him [Fig. 1], a few years before his death. As I was preparing for this speech, however, I found some other photographs from his childhood. This journey back in time reminded me of the book 
Camera Lucida, by Roland Barthes. In it, the author reflects on the nature of photography and builds his narration around a photograph of his mother as child, a photograph he decides not to show to his audience. I choose the opposite. [Fig 2] This is a photo of Jerzy Topolski and his younger brother Zbyszek. You can see my father, with a face and eyes that I recognize as familiar and which speak to me in a way similar to Barthes's punctum.

My father came from a family of teachers. Although I hardly remember my grandmother and I did not know my grandfather, I am sure that they were brave people who taught in the underground during the war, and who raised my father as a humble, honest and strong person. During the war Germans relocated my entire family to the General Government (the part of Poland that was

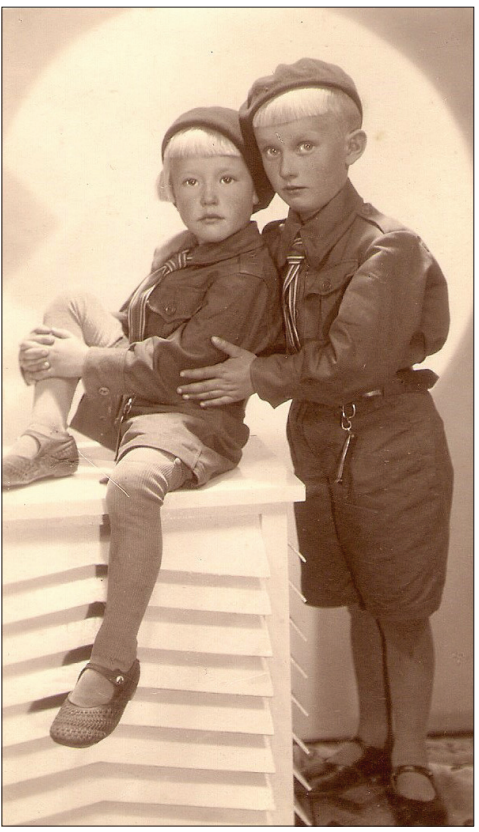
under Nazi occupation), where as a child my father took up his first job in 1944, working as an intern in a shop in Piotrków Trybunalski.

After the war my father completed his studies in the Department of Law and Economics of the Poznań's University, and in 1950 he defended his Masters Degree in Political Economy. A year later he defended his doctoral dissertation in History at the University of Nicolaus Copernicus in Toruń. In 1961 he was already a professor at the age of 33. From there, his career developed quickly. It is difficult to enumerate here all the positions he held. I will just say that he worked at the University of Poznań, the Polish Academy of Sciences in Warsaw, and the Higher School of Pedagogy in Rzeszów. He was a member of Polish and international associations and committees. Apart from being an author of so many publications, he was also an editor or co-editor of many periodicals and monographs. He was a member of the board of editors of such journals as "History and Theory", "Storia della Storiografia", "Kwartalnik Historyczny", "Studia Historiae Oeconomicae".

Jerzy Topolski pursued his academic work with a multifaceted approach. His first area of interest was social-economic history, which was the topic of his masters thesis and doctoral dissertation. In addition to these studies, he became interested, as we all know, in the methodology of history, the area that became the main focus of his work. In 1968 he published his famous Methodology of History, which was translated into 
multiple languages. This book brought him international recognition. Together with philosophers J. Kimita and L. Nowak, he cofounded the Poznań School of Methodology, combining elements of Marxist philosophy with the Western-European analytical philosophy of history. His philosophy of history evolved according to the changes in the humanities in the West. In 1983 he published Theory of Historical Knowledge, followed by How to Write and Understand History in 1996. He also studied the history of historiography and prepared numerous syntheses on regional histories (of Poznań, Gniezno, Wielkopolska) and the history of Poland.

I remember that when he died, I had to decide what I would study, as I was just completing my high school. I stood in front of a bookshelf containing all his publications and thought that I would never be able to read and understand them. I planned to study photography, but at that moment I changed my mind and decided that whatever I did with my life, I needed to study history in order to be able to understand my father, and this what was such a great passion of him. He did not know that I would choose the same field of study, but he was always a very supportive father. He sent us to schools of our choosing. Even though my brother chose to school for computer science, he had my father's support. My father organized lessons in drawing and photography for me when I was preparing for my studies, he took us abroad so we could learn about the world, and he sent me to England for a summer school, so I could study English. And he wrote in my diary: "Be persistent in whatever you do." This was also his truth; he was a very persistent person.

I have a memory of him from when I was a child. He would always tell us stories in the evenings. Every day I waited impatiently for his stories. Based on our conversations, he then wrote and publish a book. It was a history of Poland for children entitled: The Difficult Flight of the White Eagle. I have it still as a very dear memory of him and of my childhood. If he was not telling us stories, he was working in his room, and then the tapping of the typewriter was the only sound in the house. I remember that this was a very calming sound, confirming that he was at home. Interestingly, he never changed his writing habits and never substituted a typewriter with a computer. That was very typical of him. He would also take a lot of notes be hand.

His favorite place to work was Boszkowo. So many of his books and articles were created there. There he had his office, which was always open so that he could work and be present for our everyday summer activities, such as swimming, going for walks, relaxing on the terrace, picking mushrooms, and going for trips to the nearby towns. Boszkowo is a small village by a lake, where he built a summer house in the late $1960 \mathrm{~s}$ 
after publishing Methodology of History. It is a place which has a unique atmosphere. Those of you who participated in the events that he organized there know very well what I am talking about. It was a meeting place for all people from his milieu, not only historians and philosophers but also other friends from all walks of life.

But he did not spend his vacations only in Boszkowo. We would also go to Greece, as this is my mother's favorite place. There is a photo, in our family album, of him working on the beach in the shade. He would work everywhere and was very able to switch from work to relaxing, from family activities to thinking about philosophy and history. There is also this photograph [ $\mathrm{Fig}, 3]$ : depicting him dancing Zorba's dance. His last Greek journey was in October 1998, to Rodos with my mother.

Besides Greece and Boszkowo, every year in the summer we would go to Italy, to Piedmont. There, he and his very good friend Professor Raffaello Righini worked on their book Narrare La Storia, which was published in 1997. But the trips to Italy were not only for work, as we would visit the surroundings, going to such places as the seaside of Liguria. Both Professors, especially after dinner, would have endless conversations about history, society and life, that I, as a teenager, would listen to with great interest.

What I also remember from my childhood are the frequent parties and meetings my father hosted at home that gathered many different people: his fellow historians, friends, colleagues, and people from many different disciplines: artists, writers, lawyers, doctors. I remember that I would help my mother organize those gatherings, and sometimes, as I was a little child, my father would ask me to play the piano for the guests.

He was also present at family celebrations. I remember very well when, for my 18th birthday, he came back earlier from one of the conferences that he participated in, and brought me a bouquet of roses and my favorite chocolate, which were waiting for me in my room as I came back from school. The last photographs in our family album are photos from his 70th birthday in September 1998, three months before his death. Nothing would indicate then that his life was coming to an end.

As a young historian I must say that every time I begin a research project, my first steps are directed towards his publications. He gives me guidance in my own work, even though I chose some different areas of historical study. But, if I want to write about the Second World War, for example, I first go to his Poland of the Twentieth Century. And if I want to write on Poznan during the Polish People's Republic, I first reach for his Wielkopolska Throughout Centuries for further reference. And if I need methodological support, I take his How to Write and Understand History and 


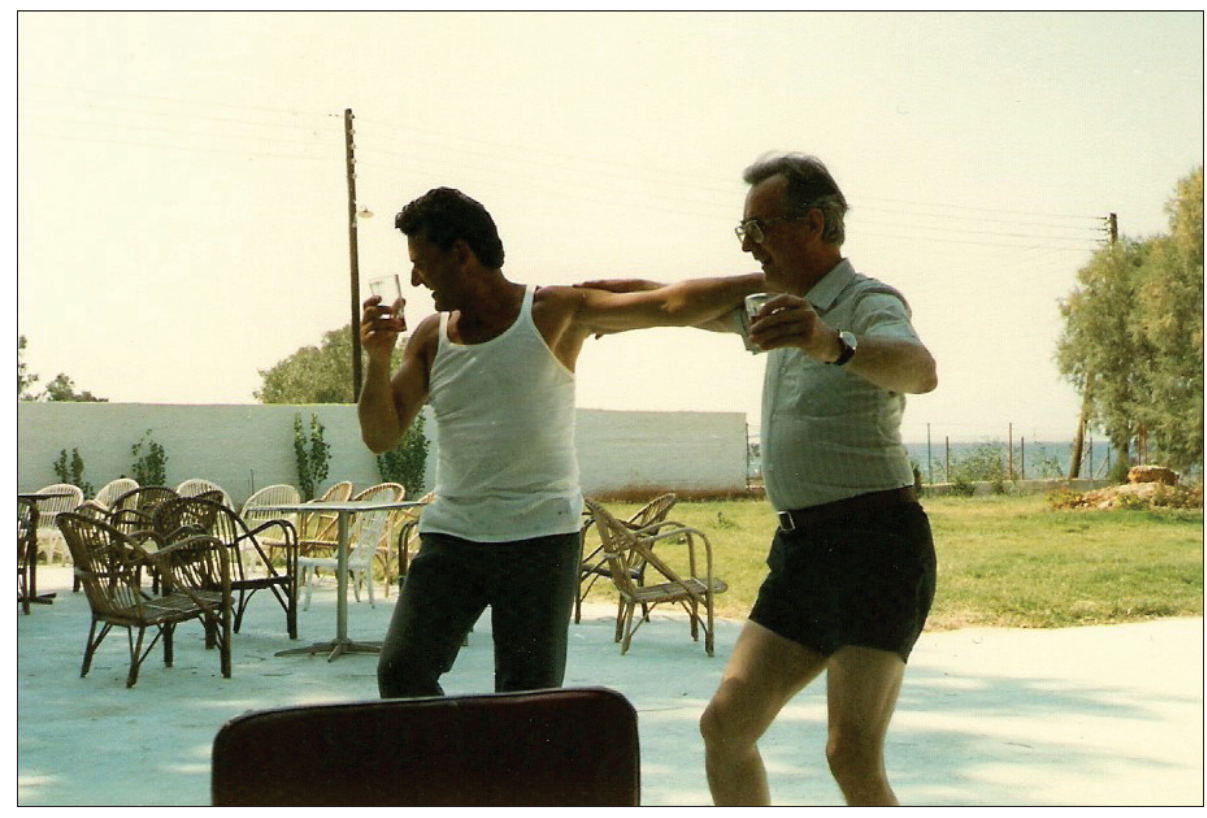

Fig. 3 .

his impossible to overestimate Introduction to History. Even when I was writing my seminar papers far away at the University of Michigan, I found his books in the library and started from there. Even though I still wish I could have conversations with him, I think it is amazing that as a historian I can still have a relationship with my father. 